\title{
Evaluation of Bacteriological Quality of Surface, Well, Borehole and River Water in Khana Local Government Area of Rivers State, Niger Delta
}

\author{
Azuonwu Obioma ${ }^{1 *}$, Azuonwu Testimonies Chikanka ${ }^{2}$ and Nwizug Wereloobari Loveth ${ }^{1}$ \\ ${ }^{1}$ Department of Medical Laboratory Science, Faculty of Sciences, Rivers State University, Nkpolu, Port, Harcourt, Nigeria \\ ${ }^{2}$ Department of Microbiology, Faculty of Sciences, Rivers State University, Nkpolu, Port, Harcourt, Nigeria
}

${ }^{*}$ Corresponding author: Azuonwu Obioma, Department of Medical Laboratory Science, Faculty of Sciences, Rivers State University, Nkpolu, Port, Harcourt, Nigeria Tel: +234 8035519688; E-mail: bimajacobs@yahoo.co.uk.

Received: July 04, 2017; Accepted: July 22, 2017; Published: July 30, 2017

Citation: Obioma A, Chikanka AT, Loveth NW (2017) Evaluation of Bacteriological Quality of Surface, Well, Borehole and River Water in Khana Local Government Area of Rivers State, Niger Delta. Ann Clin Lab Res. Vol.5:No.3:183.

\section{Abstract}

In most rural communities, water is consumed without testing its potability and the major sources of water apart from rainfall are surface and river water; in some cases, borehole water. Water samples from surface, river, well and borehole water in different Communities in Khana Local government area was randomly collected and bacteriological analysis was carried out on them. The results showed that the least microbial load was from that of borehole water which had an average microbial load of $1.78 \times 10^{3}$ while river water had the highest microbial load with a mean count of $5.48 \times 10^{4}$. Surface water, however, had the highest total coliform $(42.6 / 100 \mathrm{~mL})$ and faecal coliform count $(14.8 / 100 \mathrm{~mL})$ while borehole water had the least total coliform $(4.6 / 100 \mathrm{~mL})$ and faecal coliform (0) count. Isolation and identification of the isolates showed that Bacillus spp was the most isolated with an occurrence of 7 (23.3\%). Other organisms isolated included Staphylococcus aureus, Shigella spp, Salmonella spp, Enterobacter spp, Streptococcus spp, Proteus spp and Escherichia coli. Most of these organisms are gram negative microorganisms and are usually associated with gastrointestinal illness. Proper treatment and surveillance of these water sources should therefore be carried out regularly to prevent public health issues that could be implicated from such unwholesome practice of drinking non-potable water

Keywords: Borehole water; Coliform count; Microbial load; Gastrointestinal illness; Public health; Niger delta communities

\section{Introduction}

Water is a basic necessity for life, needed by all forms of life including plants and animals and as such a good supply of drinking water must be available to all consumers [1]. It is used in laundry, for agricultural purpose, cooking, etc. it makes up about $70 \%$ of the human body and $50 \%$ to $95 \%$ of all plants and animals [2]. In some developing countries, Nigeria inclusive, there is little or no supply of water so most residents drill boreholes, buy from water vendors in tanks, dig shallow wells [3]; in some cases, they depend wholly or partially on rainwater. The issue with these sources is that often times they are not treated and so do not meet the WHO approved standard for drinking water.

According to Grafton and Hussey [4], agriculture consumes about $70 \%$ of the world's freshwater resources. The contamination of water in its main source by agricultural, industrial or domestic wastes at certain Water microbiology which is the study of the microorganisms including fungi, bacteria, protozoa and viruses found in water is important in determining the potability of water [5]. Except for the educated, most rural dwellers consume water without testing the potability as most believe that dirt cannot harm them. Recent studies however, have disproved that fact as diseases such as cholera, hepatitis A, diphtheria, typhoid and have linked to the consumption of contaminated water. Cholera outbreak has been reported in Zimbabwe, India and Nigeria which was caused by the presence of Vibrio cholerae in municipal taps and wells [6], $80 \%$ of sicknesses and deaths among children worldwide have been associated with the consumption of unsafe water [7].

In some instances where the dwellers are aware that water is unsafe for drinking, due to poverty and probability their inability to have access to water purifiers, they are left with no choice than to make do with what they have. In Nigeria, thousands of cholera cases are recorded yearly. In addition to the presence of Vibrio cholerae (cholera), the presence of other gram-negative parasites such as Escherichia coli (gastroenteritis), Shigella dysenteriae (dysentery) and Salmonella entritidis (gastroenteritis), Mycobacterium tuberculosis (tuberculosis), Salmonella typhi (typhoid fever) are of public health concern. Viruses such as hepatitis A, polio and enteroviruses are also of concern. Giardia lambia causing giardiasis and Entamoeba histolytica causing amoebiosis are two protozoans that can be found in water which are also pathogenic in action [8]. Also, water-related diarrhoea cases have been confirmed to be the most prevalent after malaria, thus the need for the provision potable drinking water in our communities cannot be overemphasized [9]. Among those 
prone to these diseases, children under five years of age are the most susceptible mainly in Africa and Asia. The highest microbial risk is that associated with the consumption of contaminated water of either animal or human faeces by man thus, in most of the rural areas and in urban areas in some under-developed and developing countries, due to lack of toilets, most citizens tend to pass their faeces into the water bodies especially in riverine communities of Niger Delta, these sort of cultural practice is probably likely to promote the contamination of aquifer and the environment with human waste. The need to check and change the practice might literally reduce the prevalence of water borne and water based infection in our rural communities.

Among the water sources (surface water and groundwater) only $3 \%$ is safe in terms of its quality and freshness [10]. Properly drilled boreholes usually supply pure water at first, subsequently, if the water is not treated and the water tank washed, the population of microorganisms in the water increases, thus making it unsafe for drinking. This can also lead to altered physicochemistry of the water. Unfortunately, more concern is placed on the quantity on water provided and little concern is placed on its quality [11].

Studies on different water sources have shown the presence of harmful microorganisms in varied quantities depending on the study location. With regard to the quantity of microorganisms found in these samples, the water may or may not be suitable for consumption based on WHO standards. This study was thus, geared towards isolating and identifying the microorganisms found in surface, well, borehole and river water in Khana local government area of rivers state. The results from the research will provide epidemiological information and the public health risks associated with the consumption of these natural resources, if they are contaminated at certain levels. Thus, the reason for this sort of study is to obtain information that will be needed for proper management of water consumed in this area and also control and where possible prevents the increasing trends of microbial water pollution and its associated public health risk consequences.

\section{Methodology}

\section{Study area}

Khana local government area is one of the 23 local government areas in rivers state of Nigeria (Figure 1) which has Port Harcourt as its capital city. Its administrative headquarter is Bori. It has a population of 294,217 (according to the 2006 census) and a land area of $560 \mathrm{~km}^{2}$. It was created in 1992. It is located within the Niger delta region of Nigeria which is prone to environmental pollution by hydrocarbons from oil exploration. The region is shallow and as such makes the groundwater susceptible to microbiological and chemical pollution [12]. The inhabitants of this area are predominantly traders, peasant farmers and fishermen.

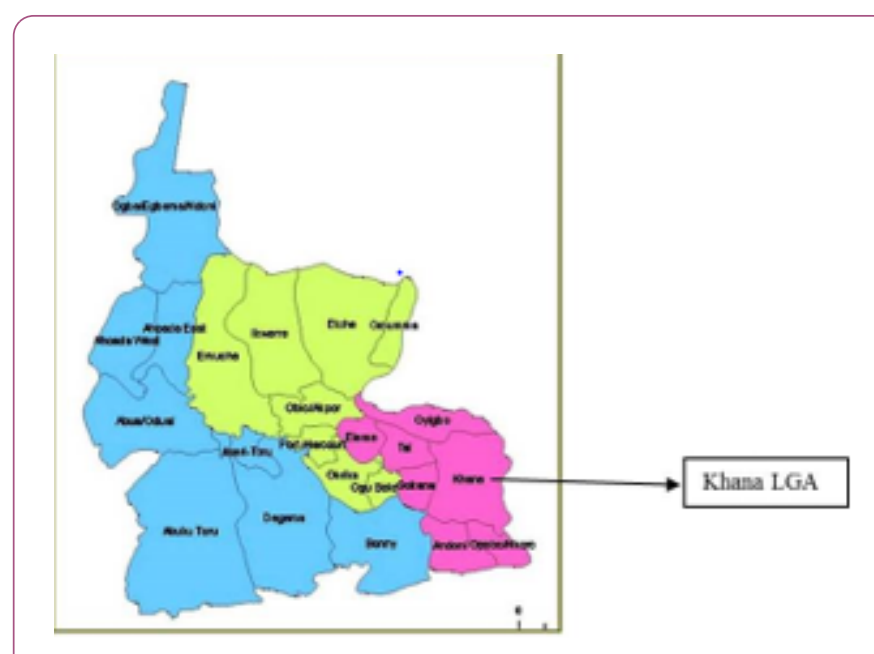

Figure 1 Map of rivers state.

\section{Sample collection}

Twenty (20) samples were randomly collected from different areas within the study area using pre-sterilized $100 \mathrm{~mL}$ bottles with caps. For the borehole water, it was allowed to run for three minutes before the sample was collected [13]. The collected samples were carefully capped, placed on ice and transported to the laboratory for microbiological analysis and the results compared with WHO standards for drinking water.

\section{Microbiological analysis}

Total and faecal coliform counts were obtained using the Most Probable Number (MPN) method. The presumptive, confirmatory and completed tests were carried out using MacConkey broth and Levine's Eosin Methylene Blue agar (EMB). The total heterotrophic count of the collected water samples was done.

The presumptive test was done by adding $10 \mathrm{~mL}$ of each water sample onto $10 \mathrm{~mL}$ of double strength (two time the normal amount of agar to the same volume of distilled water during preparation of the medium) MacConkey broth in five test tubes, $1 \mathrm{~mL}$ of sample to $10 \mathrm{~mL}$ single strength of the broth and $0.1 \mathrm{~mL}$ of sample to $10 \mathrm{~mL}$ single strength of the broth. Inverted Durham was put into each of these test tubes before the sample and both was added. The essence of the Durham tube is to trap the gas produced as the microorganisms ferment the medium. This setup is left for 24 hours at a temperature of $37^{\circ} \mathrm{C}$; after which positive tube evidenced by acid (change of colour of broth from purple to yellow) and gas production are subjected to a confirmatory test while the negative ones are left for another 24 hours. Using an inoculating loop, an aliquot from each of the first setup is transferred to a new set up with the same number of tubes and left for 24 hours. The completed test is carried out by inoculating freshly prepared and cooled Levine's EMB agar with cultures from the positive tubes in the confirmatory test for 24 hours at the same temperature. The presence of nucleated colonies with dark center is indicative of the 
presence of coliforms. The MPN of coliform bacteria in $100 \mathrm{~mL}$ of water was then determined using the MPN probability table based on the number of positive tubes in the presumptive test.

The total heterotrophic count was done by carrying out tenfold serial dilution which was first done by adding $1 \mathrm{~mL}$ of the sample to $9 \mathrm{~mL}$ of distilled water (diluent) and serially diluting it in order to reduce the microbial load and allow for picking of distinct colonies and counting, $1 \mathrm{~mL}$ from the diluted sample was plated on already prepared and cooled Nutrient Agar (CM0003, Oxoid UK) using the pour plate method and incubated at $37^{\circ} \mathrm{C}$ for 24 hours to 48 hours to enable maximum growth. A dilution factor of $10^{-4}$ was used for the River and Well samples, $10^{-5}$ for surface water and $10^{-3}$ for borehole samples. Distinct colonies on the incubated plates were sub cultured to freshly prepared Nutrient Agar and after which, Gram's stain and biochemical tests including coagulase, catalase, indole and motility tests were carried out to identify the isolated bacteria [14]. Bacterial isolates were identified based on the results from the tests according to the Bergey's Manual of Determinative Microbiology as standard [15].

\section{Statistical analysis}

Analysis of results was done using Microsoft excel package to explore and deduce the standard deviation and mean of the results as shown below.

\section{Data representation}

Results obtained were represented using table and bar chart.

\section{Results}

Bacteriological analysis of water samples from four sources in Khana local government area which included surface, river, borehole and well water was carried out. Results from these locations indicated that surface water from all five locations had the highest load compared with the river, well and borehole waters with its mean value being $2.3 \times 10^{5}$ as seen in Table 1. The least total heterotrophic colony forming units was obtained from borehole water which had a mean value of 1.78 $\times 10^{3}$. Surface water obtained from location $A$ had the highest total coliform count while locations $A$ and $D$ had the highest faecal coliform counts as shown in Table 2. Table 2 also shows that borehole water from all five locations had no faecal coliform count. Figure $\mathbf{2}$ shows that Bacillus spp was the most isolated bacteria while Shigella spp was the least isolated. Other microorganisms isolated included Staphylococcus aureus, Escherichia coli, Proteus spp, Pseudomonas spp, Streptococcus spp, Salmonella spp and Enterobacter spp.

\section{Discussion}

The presence of a group of bacteria known as coliforms in water samples serve as indicators of pollution [16]. Chief among them is Escherichia coli, which was isolated from the samples used in this study and whose presence indicates the possible presence of other intestinal pathogens. Streptococcus spp, Staphylococcus aureus, Shigella spp, Enterococcus spp, Salmonella spp, Pseudomonas spp, Proteus spp and Bacillus spp which were isolated and identified from the samples are other pathogens of importance that have been linked to gastrointestinal disorders [17].

The highest occurring microorganism in the samples was Bacillus spp. These are gram-positive, aerobic or facultative anaerobes and catalase positive microorganisms [18]. They are heat-resistant spore forming microorganisms that are most often found in soil. Due to their ability to form heat-resistant spores, they are able to survive and compete with other organisms while secreting metabolites that are antagonistic to other microorganisms in form of antibiotics [19]. Although they have been useful in the production of antibiotics, their presence in drinking water and even food poses critical health risks that may lead to diseases such anthrax.

Table 1 Total heterotrophic count of all four water sources.

\begin{tabular}{|l|l|l|l|l|}
\hline Location & $\begin{array}{l}\text { River } \\
(\mathbf{c f u} / \mathrm{mL})\end{array}$ & $\begin{array}{l}\text { Surface } \\
(\mathbf{c f u} / \mathrm{mL})\end{array}$ & $\begin{array}{l}\text { Well } \\
(\mathbf{c f u} / \mathrm{mL})\end{array}$ & $\begin{array}{l}\text { Borehole } \\
(\mathbf{c f u} / \mathrm{mL})\end{array}$ \\
\hline A & $5.6 \times 10^{4}$ & $1.8 \times 10^{5}$ & $6.8 \times 10^{4}$ & $2.0 \times 10^{3}$ \\
\hline B & $4.4 \times 10^{4}$ & $2.2 \times 10^{5}$ & $5.8 \times 10^{4}$ & $1.4 \times 10^{3}$ \\
\hline C & $8.7 \times 10^{4}$ & $1.5 \times 10^{5}$ & $4.2 \times 10^{4}$ & $1.2 \times 10^{3}$ \\
\hline D & $5.2 \times 10^{4}$ & $3.2 \times 10^{5}$ & $2.3 \times 10^{4}$ & $1.8 \times 10^{3}$ \\
\hline E & $3.5 \times 10^{4}$ & $2.8 \times 10^{5}$ & $3.5 \times 10^{4}$ & $2.5 \times 10^{3}$ \\
\hline Mean & $5.48 \times 10^{4}$ & $2.3 \times 10^{5}$ & $4.52 \times 10^{4}$ & $1.78 \times 10^{3}$ \\
\hline SD & $1.97 \times 10^{4}$ & $7.0 \times 10^{5}$ & $1.8 \times 10^{4}$ & $5.12 \times 10^{3}$ \\
\hline
\end{tabular}

Staphylococcus aureus is another gram-positive microorganism that is often associated with nosocomial infections. It is a facultative anaerobe, coagulase and catalase positive microorganism. Although they are commensals in the mucosa of mammals, reptiles and birds, they can also be opportunistic pathogens. One risk of infection by S. aureus is the issue of its resistance to beta-lactamase antibiotics including penicillin and methicillin-a derivative of penicillin. The presence of this species in water thus calls for public health concern. Streptococcus spp is also a gram-positive, catalase positive microorganism and has been associated with illnesses such as pneumonia and generally upper respiratory tract infections.

Escherichia coli, Proteus spp, Pseudomonas spp, Salmonella $s p p$, Enterobacter spp. and Shigella spp are all gram-negative microorganisms and belong to the group referred to as Enterobacteriaceae. They can cause illness such as watery and bloody diarrhoea, dysentery, urinary tract infections and when introduced into the bloodstream, they can lead to bacteremia. In addition, some strains of Escherichia coli are able to produce enterotoxins in the small intestine which can also cause diarrhea if not managed in good time. 


\section{Occurrence $(\mathrm{N}=30)$}

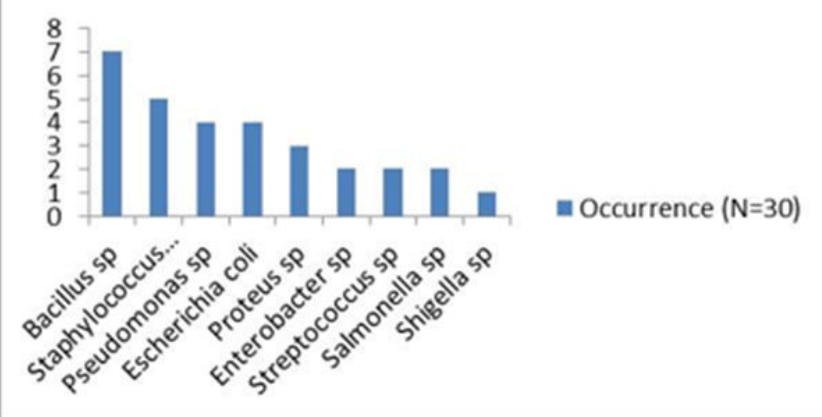

Figure 2 Coliform counts of the samples.

Table 2 Total and faecal coliform counts from water samples.

\begin{tabular}{|c|c|c|c|c|c|c|c|c|}
\hline \multirow{3}{*}{$\begin{array}{l}\text { Locat- } \\
\text { ions }\end{array}$} & \multirow{2}{*}{\multicolumn{2}{|c|}{$\begin{array}{l}\text { River } \\
\text { (MPN/100 } \\
\mathrm{mL} \text { ) }\end{array}$}} & \multirow{2}{*}{\multicolumn{2}{|c|}{$\begin{array}{l}\text { Surface } \\
\text { (MPN/100 } \\
\mathrm{mL})\end{array}$}} & \multirow{2}{*}{\multicolumn{2}{|c|}{$\begin{array}{l}\text { Well } \\
\text { (MPN/100 } \\
\text { mL) }\end{array}$}} & \multirow{2}{*}{\multicolumn{2}{|c|}{$\begin{array}{l}\text { Borehole } \\
\text { (MPN/100 } \\
\text { mL) }\end{array}$}} \\
\hline & & & & & & & & \\
\hline & $\begin{array}{l}\text { TC } \\
B\end{array}$ & $\begin{array}{l}\mathrm{FC} \\
\mathrm{B}\end{array}$ & TCB & $\begin{array}{l}F C \\
B\end{array}$ & $\begin{array}{l}\text { TC } \\
B\end{array}$ & $\begin{array}{l}\mathrm{FC} \\
\mathrm{B}\end{array}$ & $\begin{array}{l}\text { TC } \\
B\end{array}$ & $\begin{array}{l}\mathrm{FC} \\
\mathrm{B}\end{array}$ \\
\hline A & 24 & 10 & 65 & 20 & 23 & 4 & 8 & 0 \\
\hline B & 35 & 15 & 25 & 11 & 25 & 6 & 4 & 0 \\
\hline C & 23 & 8 & 23 & 5 & 32 & 5 & 5 & 0 \\
\hline D & 28 & 14 & 48 & 20 & 20 & 3 & 0 & 0 \\
\hline$E$ & 43 & 10 & 52 & 18 & 21 & 5 & 6 & 0 \\
\hline Mean & 30.6 & 11.4 & 42.6 & $\begin{array}{l}14 . \\
8\end{array}$ & 24.2 & 4.6 & 4.6 & 0 \\
\hline SD & 8.38 & 2.97 & 18.12 & $\begin{array}{l}6.6 \\
1\end{array}$ & 4.76 & 1.14 & 2.97 & $\begin{array}{l}8.3 \\
8\end{array}$ \\
\hline
\end{tabular}

TCB: Total Coliform Bacteria; FCB: Faecal Coliform Bacteria

According the results, surface water from location $D$ had the highest total heterotrophic count $\left(3.2 \times 10^{5} \mathrm{cfu} / \mathrm{mL}\right)$. This may be due to the dumping of refuse and sewage on land. In most of these areas, faeces are laid on the bare land and these pathogenic microorganisms may be transported to the surface water possibly by erosion resulting from rainfall runoff. The Borehole water had a lower microbial population probably due to the fact that the hole was drilled deep down to the point where clean water was obtained and also some boreholes are treated occasionally and the water tank washed to ensure water safety by the owners, even as the most of the boreholes are used for commercial purposes by providing drinking water to the subjects in exchange for money. The absence of faecal bacteria in borehole may be attributed to the fact that it was properly dug to get clean water; it is probably not situated close to a toilet or suck away system, regular washing and disinfection of the water tank and the presence of a water purifier which improves water quality.

Introduction of these microorganisms into water is sometimes from improper disposal of sewage and waste.
According to Krist [20], disposal of solid waste on land contributes largely to ground water pollution. Although treatment of water contaminated by pathogens or sediments is usually expensive, it cannot be compared with the cost of treatment of diseases resulting from the consumption of polluted water. In most cases, children and newborns are the most vulnerable to these water-borne diseases since their immune systems are not as developed as that of adults. In Nigeria, 15 out of the 36 states of the nation recorded about 29, 115 cases and 1191 deaths resulting from cholera in October 2010 [21].

Treatment of these contaminated water are thus very important to prevent water-borne diseases. The use of disinfectants such as boiling and the use of chlorine and its related compounds has been useful over time. Novel methods such as the use of ultrasound with frequencies above $20 \mathrm{kHz}$ have also proved to be effective in the reduction of bacterial load in water especially when it is combined with chlorine as a disinfection option [22].

The health challenge that could results from the critical issue of lack of potable water in our remote communities would be huge to manage, if urgent proactive steps are not taking in good time. Nonetheless, lack of basic water infrastructure, poverty, none functional health institutions that are closer to the village dwellers may probably worsen the entire situation, even as weak policy formulation and implementation of health and social well-being policies of the citizens by the federal, state and local government authorities would certainly have a negative correlation on the health status and outcome of the citizens [23]. It is strongly reported that underpinning the existing health facilities and providing new ones, with well-equipped diagnostic infrastructure and trained expertise will obviously help to reduce the health burden of the subjects, in our remote communities with respect to prompt diagnosis and management of water borne infections outbreak [23].

\section{Conclusion and Recommendation}

Water from these sources analyzed in this study is used for drinking, cooking, laundry and bathing purposes. If they are contaminated, there is a greater risk of water-borne diseases such as cholera, diphtheria, hepatitis A, salmonellosis and shigellosis among other. Adequate monitoring and surveillance of these water sources should therefore be carried out regularly. In cases where surveillance is not carried out, the water should be purified using chlorine, boiling or other water purification methods. Prevention of these diseases is often better and cheaper than their treatment hence, all efforts geared towards prevention of outbreak of an epidemic should be taking very seriously by all stakeholders and government and her relevant agencies.

\section{Conflict of Interest}

None was reported among authors. 


\section{Acknowledgement}

We will wish to thank Prof SD Abbey, Prof (Mrs) Wene Abbey, Joy Benson Brown and Mrs Enwereji Hope for their payers and support in cause of doing this article.

\section{References}

1. WHO (1996) World Health Organization Guidelines for drinking water quality. (3rd edn). World Health Organization of the United Nations, Rome, Italy.

2. Buchholz RA (1998) Principles of environmental management. The Greening of business. 2nd Prentice Hall, London, UK. pp. 15-42.

3. Yusuf KA (2007) Evaluation of groundwater quality characteristics in Lagos-City. J Appl Sci 7: 1780-1784.

4. Grafton QR, Hussey K (2011) Water resources planning and management, Cambridge University Press, New York, USA. pp. 21- 27.

5. Chappelle FH (2000) Ground water microbiology and geochemistry. John Wiley and Sons, New York, USA.

6. Sur D, Sarka BL, Dean J, Delta S, Niyogi SK, et al. (2006) Epidemiological, microbiological and electron microscopic study of a cholera outbreak in a Kolkata slum community. Indian J Med Res 123: 31-36.

7. WHO (2003) Guidelines for drinking water quality (3rd edn) WHO, Geneva, Switzerland.

8. Olaoye RA, Olaniyan OS (2012) Quality of rainwater from different roof material. J Eng Technol. 2: 8.

9. https://www.unicef.org/nigeria/media_2226.html

10. Kegley ES, Andrew J (1998) The Chemistry of water. (2nd edn), California: University Science books, USA 13-162.

11. Oparaocha ET, Iroegbu OC, Orji RK (2010) Assessment of quality of drinking water sources in the Federal University of Technology, Owerri, Imo State, Nigeria. J Appl Biosci 32: 1964-1976.
12. Novarino G, Warren A, Butler $H$, Lambourne $G$, Boxshall A, et al. (1997) Protistan communities in aquifers: A review. FEMS Microbiology Review 20: 261-275.

13. Bolaji TA, Tse CA (2009) Spatial variation in groundwater geochemistry and water quality index in Port Harcourt. Scientia Africana 8: 134-155.

14. Cheesbrough $M(2006)$ District laboratory practice in tropical countries. Part 2. Cambridge University Press, UK. pp. 143-157.

15. Holt JG, Krieg N, Sneath PAH, Williams ST (1994) Bergey's Manual of Determinative Bacteriology. (9th edn), Williams and Wilkins Co., Baltimore, USA. pp. 60-66.

16. Agunwamba JC (2000) Water Engineering Systems. (2nd edn) Enugu: Immaculate Publications Limited, Nigeria. pp. 133-139.

17. Nwidu LL, Obeh B, Okoriye T, Vaikosen NA (2008) Assessment of water quality and prevalence of water-borne diseases in Amassoma, Niger Delta, Nigeria. Afr J Biotechnol 7: 2993-2997.

18. Waites MJ, Morgan NL, Rockey JS, Higton G (2008) Industrial microbiology an introduction. London: Blackwell Publisher, UK.

19. Kuta FA (2008) Antifungal effects of Calotropis procera stem bank ex-tract against Trichoplyton gypseun and Epiderinoplyton Flocosum. Afr J Biotechnol 7: 2116-2118.

20. Krist AO (2000) Environmental problem in the oil rich NigerDelta in Nigeria. Newsline at Green Africa.

21. Galadima A, Garba ZN, Leke L, Almustapha MN, Adam IK (2011) Domestic water pollution among local communities in NigeriaCauses and consequences. E J of Sci Res 52: 592-603.

22. Azuonwu O, Azuonwu G, Obire O (2015) Impact of low frequency ultrasound on pathogens in polluted potable water. Scholars Journal of Applied Medical Sciences (SJAMS) 3: 1978-1984.

23. Obioma A, Chikanka AT, Omowumi OA (2017) Alteration of bacteriological load quality of rainwater due to atmospheric exposure: An alternative synergy to potable water disinfection in remote communities of niger delta of Nigeria. Ann Clin Lab Res 5: 1 . 